\title{
コンクリートの強度に及ぼす空吵欠陥の影響に関する考察 EFFECT OF MACRO-VOID ON CONCRETE STRENGTH
}

\author{
三上貴正，上沢聡史**，坂井映二*** \\ Takamasa MIKAMI, Satoshi KAMISAWA and Eiji SAKAI
}

\begin{abstract}
In this study, the relation between concrete strength and property of macro-void is investigated by testing mortar and concrete specimens containing various combination of artificial void in them. The shapes of macro-void in the experiment are sphere, circle disk and oval disk. As a result, the estimate strength obtained from the following equation showed adequate correlation with the measured strength.
\end{abstract}

$\mathrm{Fc} / \mathrm{Fc}_{0}=\exp (\mathrm{a} \mathrm{Az})$, where $\mathrm{Fc} / \mathrm{Fc}_{0}$ : relative strength of concrete, $\mathrm{Az}$ : maximum ratio of projected sectional area of void, a : constant.

Keywords : Macro-void, Property of void, Artificial void, Relative strength of concrete,

Maximum ratio of projected sectional area of void

空隙欠陥、欠陥性状、モデル欠陥、圧縮強度比、最大投影欠陥断面積比

\section{1. 序論}

近年、建設後10 20年という早い時期に、劣化現象を示すコンク リート構造物が多数存在することが社会的問題となっている。この ような早期劣化が生じた構造物の被害報告によると、その約半数は 施エ中に生じた欠陉に起因するものであり、現場でのコンクリート の調合、打設および養生の不具合が欠陥の主な原因であると指摘さ れている"2)。このように、コンクリート構造物の強度や耐久性に 関しては施工の良否が著しく影響を及ぼすが、とりわけコンクリー ト構造物は型枠内部への十分なコンクリートの充填を前提としてい るため、締固め不足などでコンクリートの充填が不十分な場合は、 耐久性か低下したり設計基準強度に達しないなど、要求される性能 水準を確保できなくなることがある。

以上より、コンクリート構造物の耐久性、信頼性、安全性向上の 観点から、コンクリートの充填度を測定、評価する必要があると考 えられる。さらに、昨今、P C 型枠や鋼管コンクリート柱など、コ ンクリート硬化後も脱型しない新たな構造型式が塞用化されてきて おり、これらに関してはより一層、充填度を検查する必要性が高ま っていくと考えられる。

コンクリートの型枠内への充填状況や内部空隙欠陥のモニタリン グシステムの構筑に関しては、これまでにも様々な研究が行われて
おり、各種の方法が提案されている3，4)。しかしながら、欠陥性状 とコンクリートの品質との関係についての定量的検討が不足してい るため、測定対象とすべき欠陥の範囲や指標とすべき欠陥のパラメ 一夕は明確にされておらず、コンクリート打設時や硬化後の充填状 況の検查は、適正に行われていないのが現状である。したがって、 施工不良による欠陥の性状がコンクリートの品質に及ぼす影響を明 らかにすることが必要であると考えられる。

本研究は、コンクリート構造物の品質に及ぼす内部空隙欠陥の影 響を定量的に評価するための基礎的段階として、モデル空隙欠陥を 有する供試体に関して、欠陥の性状がコンクリートの最も基本的な 品質項目である圧縮強度に及ぼす影響を実験的に把握し、コンクリ 一トの充填状況を把握する際に指標とすべき空隙欠陥のパラメー夕 に関して考察することを目的としたものである。

なお、本研究で対象とする欠陥は、コンクリートの充填が不十分 な場合に生ずる、いわゆるジャンカなどに代表される、コンクリー トの表面や断面において目視による判別が可能な大きさの空隙欠陥 （以降、マクロな空隙欠陥と記す）とした。ただし、基礎的段階に ある本論文では、対象とする空隙欠宿の形状は比較的単純なものに 限定し、実際の施工不良により生じることの多い不整形な形状の空 隙欠陷に関しては、次報以降の課題とした。
* 東京工業大学大学院情報理工学研究科 助教授・工博

** 旭硝子侏(当時東京工業大学大学院生) 修士(工学)

*** 東京工業大学工学部建築学科 助手. 修士 (工学)
Assoc. Prof., Graduate School of Information Science and Engineering, Tokyo Institute of Technology, Dr. Eng.

Asahi Glass Co., Ltd., M. Eng.

Research Assoc., Dept. of Architecture and Building Engineering, Faculty of Eng. Tokyo Institute of Technology, M. Eng. 


\section{2. 実験概要}

供試体の調合、およびモデル欠陥の性状の範囲を設定し、モル夕 ル・コンクリート供試体の圧縮強度試験を行った。以下に、主要な 事項について説明する。

(1) 調合の設定

基本となるモルタル・コンクリートには、モデル欠陥以外の空隙 欠陷や材料分離が極力発生しないように、均質で安定した性状を持 つものが求められる。また、モデル欠陥の配置の制御を容易とする ため、流動性に優れた、自己充填性を有するものが求められる。以 上の 2 点を基本方針とし、調合を設定した。

(1) 使用材料

使用材料を表 1 に示す。セメントは普通ポルトランドセメントを 用い、モルタル・コンクリートは流動性に優れ、材料分離を生じな いものとするため、混和剤としてナフタリンスルホン酸塩系高性能 減水剂を使用した。本研究ではモテル欠陷以外の空隙の発生をでき るたけ抑えるという基本方針から、混和㓮も A E 作用のないものと した。骨材に関しては、骨材の不均一さによる影響を少なくするた め、均質で安定した性状を持つように通常より最大寸法を小さいも のとした。細骨材は、モルタルには最大寸法 $600 \mu$ 几の(亿)を用い、 コンクリートには最大寸法 $2.5 \mathrm{~mm}$ の(口)を用いた。冝骨材の骨材寸法

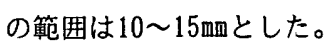

(2) 調合の設定

試し繒りにより、要求される条件を満たす調合を設定し、水セメ ント比(H/C)35\%、砂セメント比 $(\mathrm{S} / \mathrm{C}) 100 \%$ 、混和剤添加率 $(\mathrm{A} / \mathrm{C}) 2.4 \%$ のモルタルを基本調合とした。また、W/Cの違いによるセメント硬 化体構造の差異の影響をみるため、比較的組織が粗墨なものとして W/C:70\%のもの、および、W/Cによる強度算定式 ${ }^{5}$ から求めた、これ らの中間の強度に相当するW/C: $46 \%$ もの、計 3 種のH/Cの調合を設 定した。なお、S/C、A/Cは試し縲りにより、モルタルフローが基本 調合と同程度となるように設定した。また、粗骨材の有無による影 響をみるため、コンクリートもあわせて設定した。コンクリートの モルタル部分の調合は、先に設定したモルタルと同様、W/Cの異な る3 種を設定し、冝骨材の割合はいずれも、コンクリート重量の40 \%とした。表 2 に調合を示す。

\section{(2) 赛験条件の設定}

強度に影響を及ほす空隙欠陥の因子として、欠陷の形状・寸法・ 量・配置に着目し、モデル欠陥の性状の範囲を設定した。モデル欠 陥には、強度が母材の強度と比較してほぼ０とみなせる、発泡スチ ロールを使用した。形状は、最も単純な球状、および配置によって 強度に及ほす影響が大きく異なるであろうと考えられる、板状の 2 種を設定した。欠陥寸法は、球状モデル欠陥では直径 $12 、 20 、 30 、$ $40 \mathrm{~mm}$ の 4 種、轩状モデル欠陥では、直径 $20 \mathrm{~mm}$ で厚さ $5 \mathrm{~mm}(\mathrm{C} 1)$ 、なら びに、直径 $40 \mathrm{~mm}$ 、厚さ $3 \mathrm{~mm}(\mathrm{C} 2)$ と $5 \mathrm{~mm}(\mathrm{C} 3)$ の円板状のもの、および、 厚さ $3 \mathrm{~mm}$ 、長径 $90 \mathrm{~mm}$ 、短径 $40 \mathrm{~mm}(01)$ 、ならびに、長径 $55 \mathrm{~mm}$ 、短径 $40 \mathrm{~mm}$ (02)の楕円板状のものの 5 種とした。球状モデル欠陥の配置は、 欠陥が 1 力所に集中したものを模した $\mathrm{A}$ 、比較的均等に存在する $\mathrm{B}$ 、 横方向に偏って存在するC、縦方向に偏って存在する $\mathrm{D}$ など、計 8 種の配置を設定した。板状モデル欠陥の配置は載荷方向に対する角 度 $\theta$ が、0、45、90度および、 $\tan \theta=1 / 2$ となる、26.6度の 4 種を 設定した。図 1 にモデル欠陥の配置を示す。
表一 1 使用材翗

\begin{tabular}{|c|c|c|c|c|}
\hline 材 料 & \multicolumn{3}{|c|}{$\begin{array}{l}\text { 種 類 } \\
\end{array}$} & 比重 \\
\hline セメント(C) & \multicolumn{3}{|c|}{$\begin{array}{c}\text { 普通ポルトランド } \\
\text { セメント }\end{array}$} & 3.15 \\
\hline 混和剂(A) & \multicolumn{3}{|c|}{$\begin{array}{c}\text { ナフタリンスルホン酸塩系 } \\
\text { 高性能娍水斑 }\end{array}$} & 1.20 \\
\hline 骨材 & 種類 & 比重 & 吸水率 & 踥径 \\
\hline 細骨材 (1)(S) & \multirow{2}{*}{$\begin{array}{l}\text { 千葉目産 } \\
\text { 山砂 }\end{array}$} & \multirow[t]{2}{*}{2.61} & \multirow[t]{2}{*}{$1.56 \%$} & $<0.6 \mathrm{~mm}$ \\
\hline 細骨材(口)(S) & & & & $<2.5 \mathrm{~mm}$ \\
\hline 祖骨材 (G) & 砕石 & 2.57 & $0.73 \%$ & $10 \sim 15 \mathrm{~mm}$ \\
\hline
\end{tabular}

表一2 供試モルタル・コンクリートの調合

\begin{tabular}{|c|c|c|c|c|c|c|}
\hline & \multirow{2}{*}{$\begin{array}{l}W / C \\
(\%)\end{array}$} & W & A & C & $S$ & G \\
\hline & & \multicolumn{5}{|c|}{$\left(\mathrm{kg} / \mathrm{m}^{3}\right)$} \\
\hline \multirow{3}{*}{ Eル夕ル } & 35 & 311 & 23 & 955 & 955 & - \\
\hline & 46 & 392 & 5 & 862 & 862 & - \\
\hline & 70 & 407 & 4 & 586 & 1055 & - \\
\hline \multirow{3}{*}{ コンクリート } & 35 & 187 & 14 & 573 & 573 & 1028 \\
\hline & 46 & 235 & 3 & $\begin{array}{lll}5 & 17\end{array}$ & 517 & 1028 \\
\hline & 70 & 244 & 2 & 352 & 633 & 1028 \\
\hline
\end{tabular}

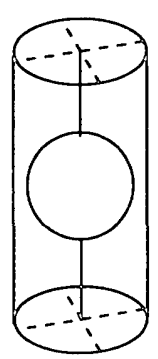

A

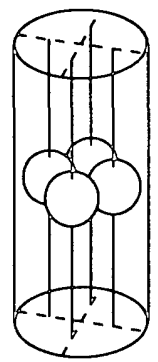

E

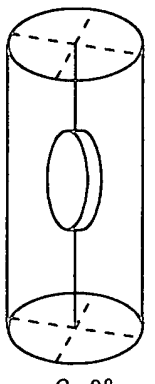

$\theta=0^{\circ}$

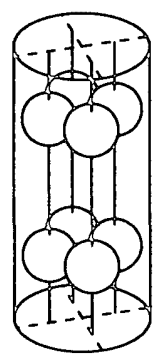

B

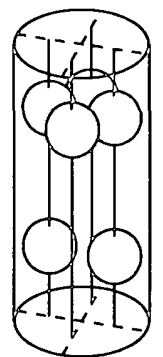

F

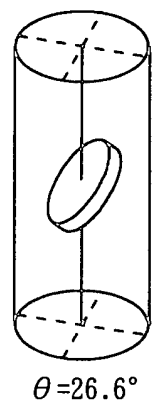

図一 1 モデル欠陥の配置

C

G
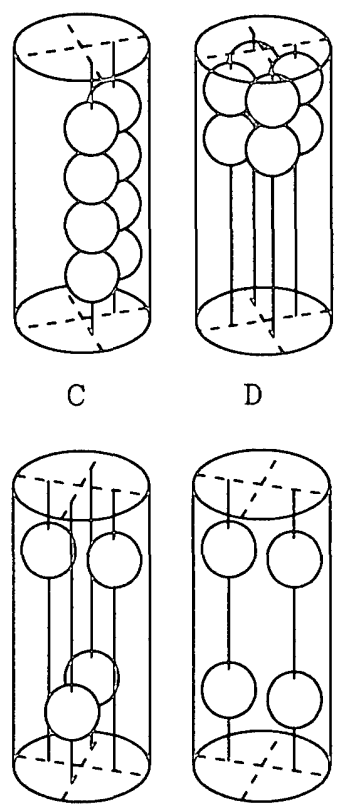

$\mathrm{D}$

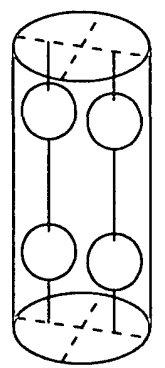

$\mathrm{H}$

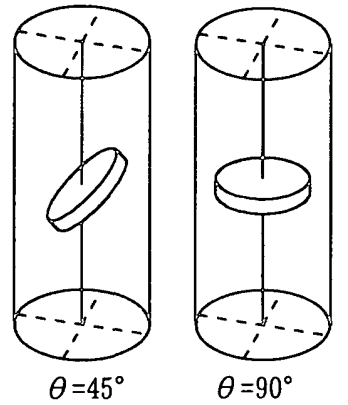

$\theta=90^{\circ}$
供試体は $\phi 5 \times 10 \mathrm{~cm}$ の円柱状のものを基本とし、寸法の違いによ

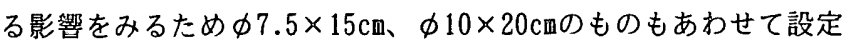
し、計 3 種とした。

以上、モルタル・コンクリートの調合、モテル㫿の形状・寸法 
表 -3 実験条件

\begin{tabular}{|c|c|c|c|c|c|c|c|c|c|c|c|c|c|c|c|c|}
\hline & & 状 & $\overline{E \bar{E}}$ & 儿欠 & 侸を有す & 共言 & & & & & 板状 & デル & 它を有 & 供 & & \\
\hline 供試体寸法 & & $\mathrm{V} / \mathrm{C}$ & & 和骨葋 & & 25 & & 空隙率 & & 体寸注 & $\phi 5$ & 100 & W/C : & $5 \%$ & モルタル & \\
\hline (cm) & & $\%$ & & D有䇥 & 直径 & 数 & 配置 & & & & & :デル & & & & 空隙率 \\
\hline & 35 & 46 & 70 & & $\mathrm{D} v(\mathrm{~mm})$ & & & $\mathrm{Pv}(\%)$ & 記㞻 & 形状 & 直径 & 長膲 & 短径 & 厚さ & 配置 & \\
\hline & 0 & 0 & 0 & & 20 & 1 & $\bar{A}$ & 2.13 & & & & & & & $\theta$ (度) & $\mathrm{Pv}(\%)$ \\
\hline & 0 & & & & 30 & 1 & $\bar{A}$ & 7.20 & & & 20 & - & $\overline{-}$ & 5 & 0 & 0.80 \\
\hline & 0 & & & & 40 & 1 & $\mathrm{~A}$ & 17.07 & C 1 & & 20 & - & - & 5 & 45 & 0.80 \\
\hline & 0 & & & & 12 & 8 & $\mathrm{~B}$ & 0.46 & & & 20 & - & - & 5 & 90 & 0.80 \\
\hline & 0 & & & & 20 & 8 & $\mathrm{~B}$ & 17.07 & & & 40 & - & - & 3 & 0 & 1.92 \\
\hline$\phi 5 \times 10$ & 0 & & & & 20 & 8 & $\bar{C}$ & 17.07 & & & 40 & - & - & 3 & 26.6 & 1.92 \\
\hline & 0 & & & & 20 & 8 & $\mathrm{D}$ & 17.07 & C 2 & 円 & 40 & - & - & 3 & 45 & 1.92 \\
\hline & 0 & & & 無 & 20 & 4 & $\mathrm{E}$ & 8.53 & & & 40 & $\overline{-}$ & - & 3 & 90 & 1.92 \\
\hline & 0 & & & & 20 & 6 & $\bar{F}$ & 12.80 & & & 40 & $\overline{-}$ & - & 5 & 0 & 3.20 \\
\hline & 0 & & & & 20 & 4 & $\mathrm{G}$ & 8.53 & & & 40 & - & - & 5 & 26.6 & 3.20 \\
\hline & 0 & & & & 20 & 4 & $\mathrm{H}$ & 8.53 & C 3 & & 40 & - & 二 & 5 & 45 & 3.20 \\
\hline & 0 & & 0 & & 20 & 1 & $\bar{A}$ & 0.63 & & & 40 & - & - & 5 & 90 & 3.20 \\
\hline$\phi 7.5 \times 15$ & 0 & & 0 & & 30 & 1 & A & 2.13 & & & - & 90 & 40 & 3 & 0 & 4.32 \\
\hline & 0 & & 0 & & 20 & 1 & $\mathrm{~A}$ & 0.27 & 01 & & - & 90 & 40 & 3 & 26.6 & 4.32 \\
\hline$\phi 10 \times 20$ & 0 & & 0 & & 40 & 1 & $\mathrm{~A}$ & 2.13 & & 楕円 & - & 55 & 40 & $\overline{3}$ & 0 & 2.64 \\
\hline & & & & & & & & & 02 & & - & 55 & 40 & 3 & 26.6 & 2.64 \\
\hline$\phi 10 \times 20$ & 0 & O & 0 & 有 & 40 & 1 & A & 2.13 & & & - & 55 & 40 & 3 & 45 & 2.64 \\
\hline
\end{tabular}
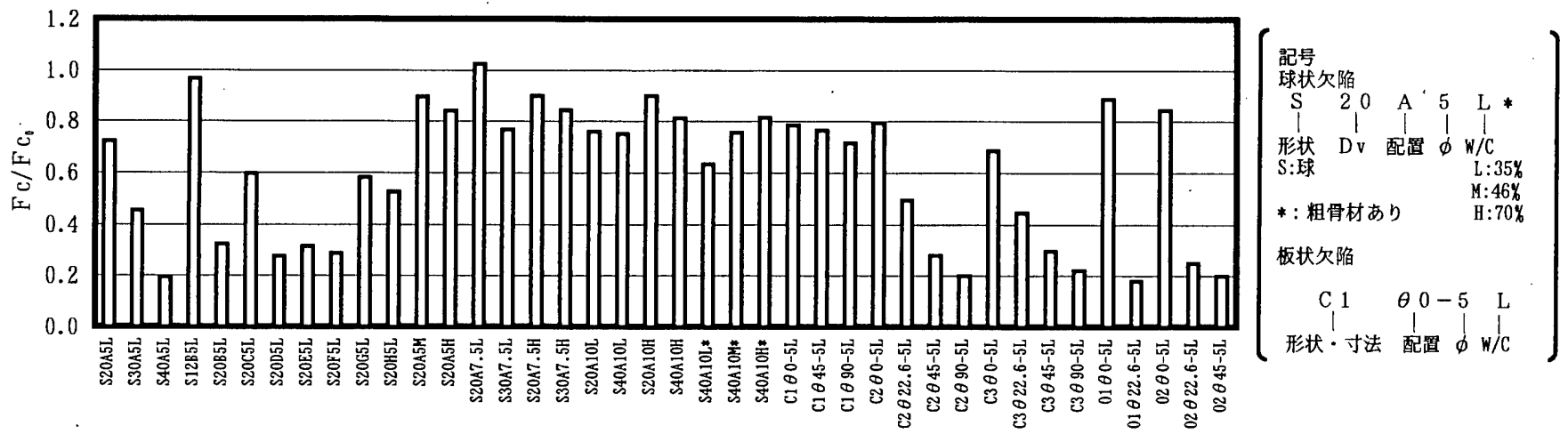

図2 欠陥性状の異なる供試体の F c/ F c。

・配置、供試体寸法の組み合わせよりなる、表 3 に示す実験条件を 設定した。

（3）圧縮強度試験

試験材齢は $40^{\circ} \mathrm{C}$ 水中養生で 1 週、試験体数は 1 条件につき 4 体と した。所定材跉に達した供試体を用いて、JIS A 1108「コンクリー トの圧縮強度試験方法」に準じて圧縮強度試験を行った。

\section{3、実験結果および考察}

(1) 実験結果

図 2 に圧縮強度試験結果を示す。強度の指標としては、欠陥の存 在による圧縮強度（F c ）の低下の割合をみるため、同一の調合、 供試体寸法でモデル欠陥を持たない供試体の圧縮強度（ $\mathrm{F}_{0}$ ) を基 準とした圧縮強度比（Fc/ F co）を用いた。図 2 より、モデル欠陥 の存在により強度が低下すること、また、低下の割合は欠陌性状に より大きく異なることがわかる。

（2）欠陥性状の影響に関する考察

(1) 欠陥の量の影響

既往の研究より、脆性多孔質材料の空隙率 (Pv) と強度との間 には高い相関があるといわれている ${ }^{6)}$ 。図 3 に、モデル欠陥のP $\mathrm{P}$ と $\mathrm{F} \mathrm{c} / \mathrm{F} \mathrm{c}_{0}$ との関係、および既往の強度推定式による一般的な多孔 質材料（実線）とコンクリート（破線）の場合の、Pvをパラメー タとした F c/ F $c_{0}$ の推定曲線を示す。

図3より、マクロな空隙欠陥を有するモルタル・コンクリートの

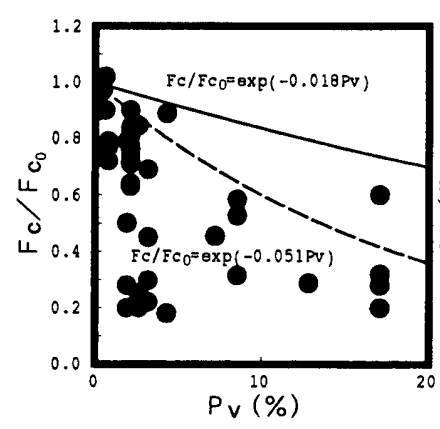

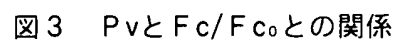
および一般的な強度推定式

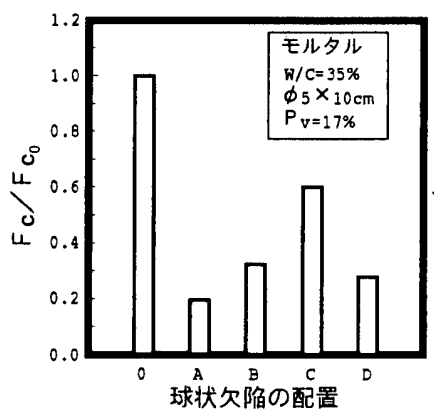

図 5 久陥配置の異なる

供試体の F c/ F co（球状欠陥）

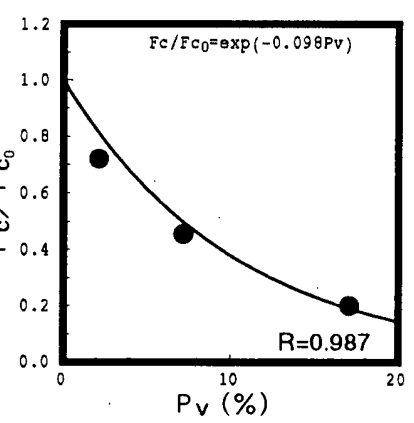

図4 Pvと Fc/Fcoとの関係 およびその近似曲線

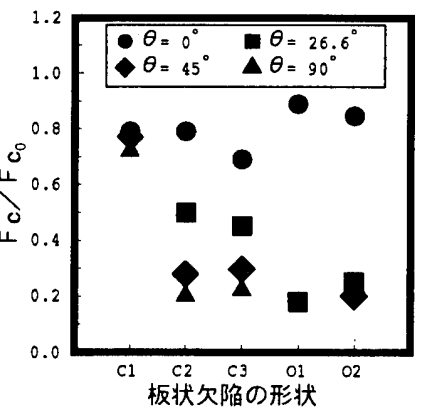

図6 次陷配置の異なる 供試体の F c/ F co（板状欠陥） 
$\mathrm{Fc} / \mathrm{F} \mathrm{c}_{0}$ は、硬化セメントペースト中のミクロな空隙を主な対象と する $\mathrm{F} \mathrm{c} / \mathrm{F} \mathrm{c}_{0}$ の推定值に比較して低くなる傾向があることかわかる。 これは、マクロな空隙欠宿の場合、欠竹への応力集中の度合が高い ため、均等に空隙が分散している場合に比較して強度が低下しやす いためと考えられる。また、同一のPvでも、強度の低下の割合に 差が生じることがわかる。図 4 に欠陥配置が同一で、Pvの異なる 供試体のPvと F c/F coとの関係、およびその指数近似曲線を示す。 これより、同一の久陥配置では Pvと F cとの間には高い相関がある ことがわかる。つまり、逆に言えば、ミクロな空隙の場合は、空隙 がより均一に分散していることもあって、空隙の配置の影響は結果 として十分小さくなっているといえる。

(2) 欠陥の配置、形状の影郘

図 5 に調合、供試体寸法、Pvが同一で、欠陥配置の異なる、球 状モテル欠陥を有する供試体の $\mathrm{F} \mathrm{c/F} \mathrm{c} 0$ 、図 6 に調合、供試体寸法、 $\mathrm{P} v$ が同一で、欠陥配置（ $\theta$ : モテル欠陥が载荷方向となす角度）

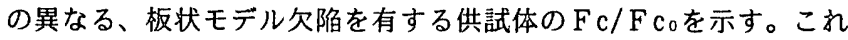
らより同一のPvでも欠陥配置の違いにより、F / F coに差が生じ ることがわかる。特に、板状欠陥の場合、全く同一の欠陥であって も、配置 $(\theta)$ の違いにより、 $\mathrm{Fc} / \mathrm{Fc}_{0}$ の最大值と最小值との比が最 大4.9となっており、配置の影響が非常に大きいことがわかる。

図 7 に $\theta$ と $\mathrm{F} / \mathrm{Fc}_{0}$ との関係を示す。これより、板状欠陷の場合、 同一の欠陥では $\mathrm{F} \mathrm{c} / \mathrm{F} \mathrm{c}$ 。は $\theta$ と高い相関があることがわかる。

以上から、マクロな空隙欠陥が卓越して強度に影響を与える場合

は、久陥の形状や配置の影響の度合いが大きいことがわかる。

(3) W/Cの影郘に関する考察

図 8 に同一の欠陥性状、供試体寸法で岁/Cの異なる供試体のW/Cと

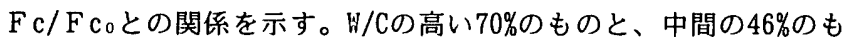
のとでは F c/ F c o はほほ同等で、W/Cの違いによる影響は明確では ないか、、/Cの低い $35 \%$ ものは他の 2 つに比較して、強度の低下か 著しい。これは、H/Cの低い高強度のもののほうか、より脆性的傾 向か顕著になり、欠陷の影響に敏感となるためと考えられる。した がって、今後のコンクリートの高強度化を考虑すれば、マクロな空 隙欠俩の抑制はより重要な䛺題といえる。

（4）供試体寸法の影響に関する考察

図 9 にモテル欠陥を持たない供試体の供試体横断面の直径 $(\phi)$ と Fcとの関係、また図 10 に同一の調合、久陥性状で 供試体の じ場合、強度は供試体寸法が大きくなるほど低下するといわれてい る。一方、非均質脆性材料であるモルタル・コンクリートの場合、 供試体寸法が大きくなるほど、ゲル空隙や毛細管空隙、あるいは応 力集中が生じる硬化セメントペーストと骨材との界面などの潜在的 な欠陥の存在確率が高くなるため、マクロな空隙欠陥による影谙は 緩和されると考えられる7。しかしながら、モデル欠陥を持たない 供試体では、供試体寸法が大きくなるほど Fcは同等かやや高い

（図 9 ）。また、久陥の相対量が同じ（Pv:2.13\%）場合は、Fc/ F c 。はほぼ等しく、供試体寸法の違いによる影響は明確にはみられ ない（図 100$)$ 。

(5) 冝骨坊の影鄵に関する考察

図 11 にモデル欠陥を持たないモルタル・コンクリート供試体の F cを示す。W/C:35\%、70\%ともにモルタルのほうがコンクリートよ

りも強度が高い。これは、コンクリートは婰骨材の存在により骨材 下部の水隙、硬化セメントペーストと骨材との界面に形成される脆 弱な選移帯など応力集中が生じる界面が存在しゃすくなり、同一の W/Cでもモルタルに比較して強度が低下するためと考えられる ${ }^{8)}$ ．9)。

図 12 に同一の供試体寸法、欠陷性状を有するモルタル・コンク リートの F c/F coを示す。H/C:70\%では数骨材の存在による影鄕は みられないが、溥:35\%ではコンクリートのほうが強度の低下が著 しい。これは、低水セメント比のほうが、粗骨材の存在の影響に敏 感となるためと考えられる。

\section{4. 強度推定式の諔刑、提示}

設定したモデル欠陥の性状ならびに圧縮強度試験の結果より、久 陷性状と F c F F c と関係について回帰分析を行い、F $\mathrm{Fc} / \mathrm{Fc}_{0}$ の推 定式の誘導、提示を通じて、空隙欠陥の性状がコンクリートの圧縮 強度に及ぼす影響を考察することとした。

（1）球状欠陥を有する供試体に関する検討

既往の研究より、一般に脆性多孔質材料のPvと F cとの間には高

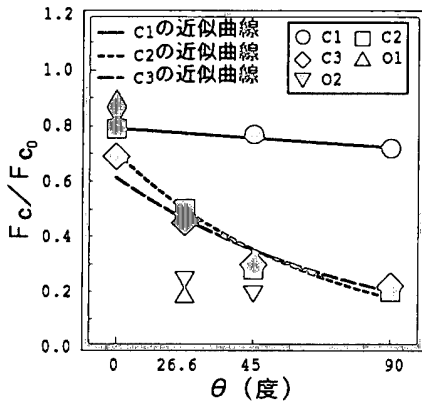

図 $7 \theta$ と F / F coとの関係

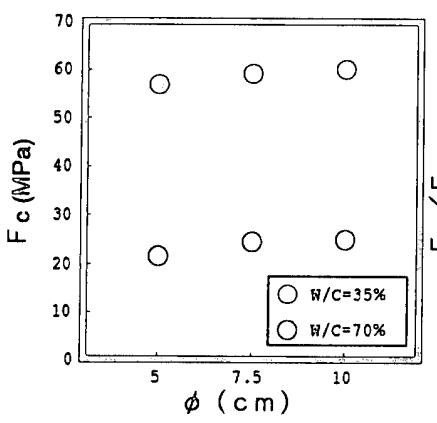

図 9 モデル欠陥を持たない 供試体の ゆと F Cとの閶係

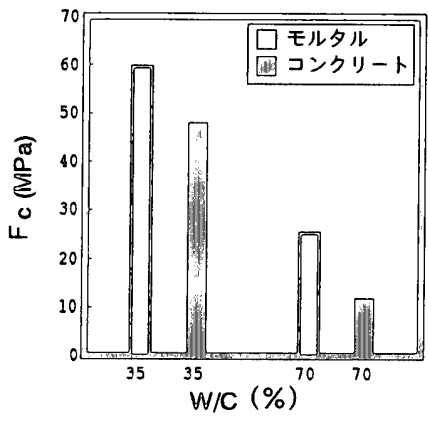

図 11 モデル欠陥を持たない モル夕ル・コンクリートの F c

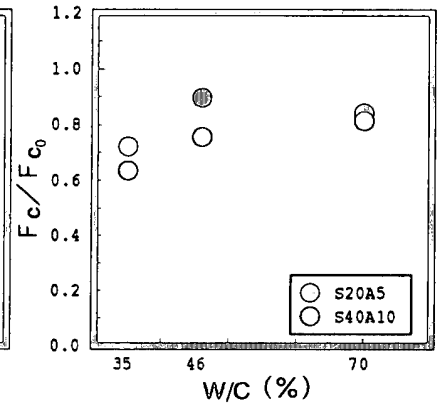

図 $8 \mathrm{~W} / \mathrm{C}$ と $\mathrm{F} / \mathrm{Fc}_{0}$ との關係

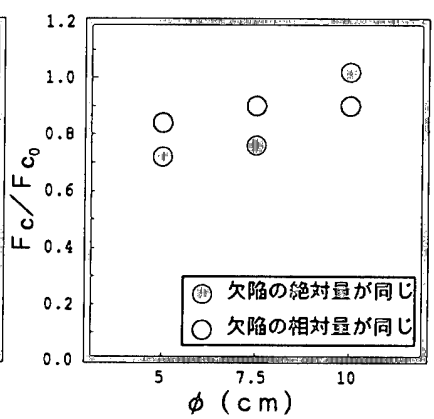

図１0 モデル欠陥を有する 供試体の ゆと F c/F coとの関係

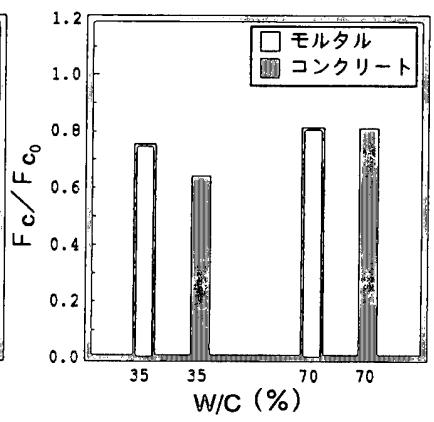

図12 モデル欠陥を有する 现外・コン舛ートの F c/ F c。 
い相関があるといわれている。Pvによる強度推定式として、Ryshkewitchの式 ${ }^{6)}$

$$
F c=F c_{0} \exp (-\mathrm{a} P v)
$$

との対応について検討した。(1)式を変形して、回帰分析を行った 結果(2)式を得た。

$$
F c / F c_{0}=\exp (-0.077 P v) \quad(\mathrm{Pv} \leqq 17.07 \%)
$$

図 13 に、Pvと Fc/Fc。の実測值との関係および(2)式による推定

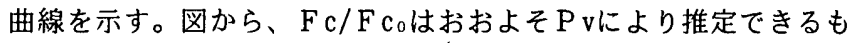
のの、同一の $\mathrm{P} v て ゙ も ~ F c / F c_{0}$ の相違は小さくない場合のあること がわかる。

また、コンクリートの強度はPvに加えて、空隙径（Dv）にも影 響を受けると報告されており、Pvのみによる強度推定式よりも対 応のよい、PvとDvによる(3)式が提案されている(0)，11。

$$
F c=\exp \{a P v+b \ln (D v)+c\}
$$

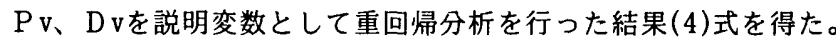

$$
F c / F c_{0}=\exp \{-0.065 P v-0.044 \ln (D v)\}
$$$$
\text { ( } \mathrm{P} v \leqq 17.07 \%, D \mathrm{v} \leqq 20 \mathrm{~mm})
$$

図 14 に(4)式による F c/ F c o の実測値と推定値との対応を示す。 (4)式も対応は十分とはいえない。(1)〜 (4)式で対象としている空 隙は、コンクリートの場合、硬化セメントペースト中のゲル空隙や 毛細管空隙、エントレインドエアーといったコンクリート中にほぼ 均等に分散するミクロな空隙であるが、以上より、マクロな空隙欠 陥を有するコンクリートの強度は、これらの推定式では十分には推 定できないことがわかる。

また、図 5 より、同一の欠陥量でも配置の違いにより強度の低下 の割合に差が生じており、中でも配置 Cは他の配置と比較して、強 度の低下は小さい。これは配置 Cでは、載荷方向に垂直な平面で切 断した欠陥の断面積と、供試体の載荷方向に垂直な断面の面積との 比（欠陌断面積比）の最大值か、他の配置の $1 / 2$ と小さいためと考 えられる。そこで、マクロな空隙欠陥を有するコンクリートの強度 は、最弱部分を示す最大欠陷断面積比（Ar) に強く影響を受けて いると考え、Arを説明変数として F / F c o と A rとの間に指数関係 を仮定して回帰分析を行い、結果として(5)式を得た。

$$
F c / F c_{0}=\exp (-1.959 A r) \quad(\mathrm{Ar} \leqq 0.64)
$$

図15にArの概要を示す。

図 16 に Arと Fc/ F $c_{0}$ の実 測值との関係、および(5)式 による推定曲線を示す。 (4)式より(5)式の方か.実測 值と推定値との対応がよい ことがわかるこれより、 球状欠陷がコンクリートの 強度に及ぼす影響は、Pvや、 PvとDvの組み合わせより Arを用いたほうが適切に表 現できるといえる。

（2）板状欠陥を有する供試

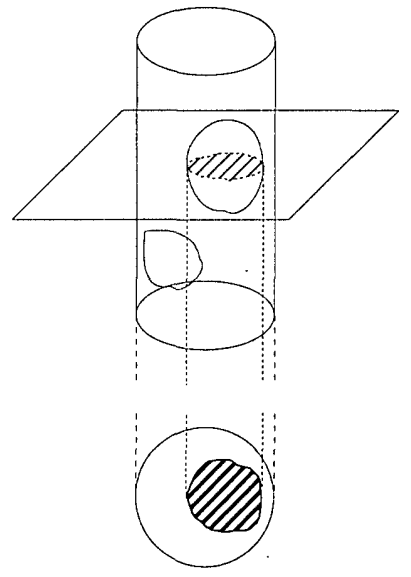
体に関する検討

板状欠陥を有する供試体 の圧縮強度試験結果につい

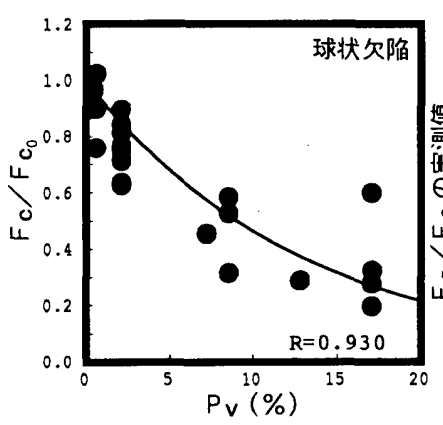

図 $13 \mathrm{Pv} / \mathrm{Fc} / \mathrm{Fc}_{0}$ との関係 およひ(2)式による推定曲線

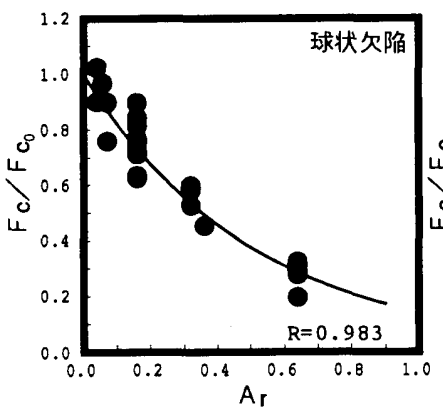

図16 Arと Fc/F coとの関係 および(5)式による推定曲線

てPvを説明変数として回帰分 析を行った結果(6)式を得た。

$F c / F c_{0}=\exp (-0.317 P v)$

( $\mathrm{Pv} \leqq 4.32 \%)$

(6)式

図 17 にPvと Fc/F $c_{0}$ の実測値 との関係、および(6)式による推 定曲線を示す。球状モデル欠陥を 有するものよりも、実測值と推定 值との対応性はさらに低下してい る。そこで、球状モデル欠陥を有 するもので対応の良好であった、 Arを説明変数として回帰分析を 行った結果(7)式を得た。

$$
\begin{gathered}
F c / F c_{0}=\exp (-3.128 A r) \\
(\mathrm{Ar} \leqq 0.64) \quad(7) \text { 式 }
\end{gathered}
$$

図 18 に Arと Fc/F 0 の実測値 との関係、および(7)式による推 定曲線を示す。これも(6)式と同 様、対応はよくない。これは、 3 . (2)(2)で述べたように、久陷 配置が強度に影響を与えるためと 考えられる。次に、欠陷を載荷 方向に垂直な平面に投影した面積 （欠陥投影面積）と供試体の載荷 方向に垂直な断面の面積との比 （投影欠陷面積比：Ap）を用いて 検討を行った。図19にApの概

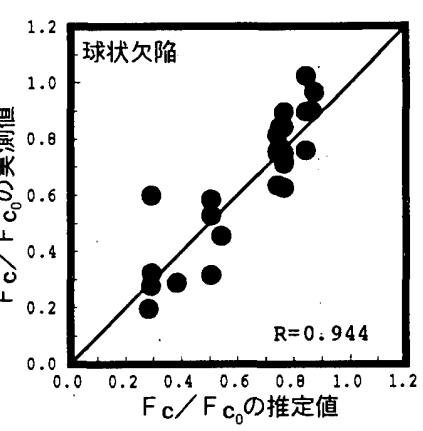

図 $14 \mathrm{Fc} / \mathrm{Fc}_{0}$ の実測值と

(4)式による推定值との対応

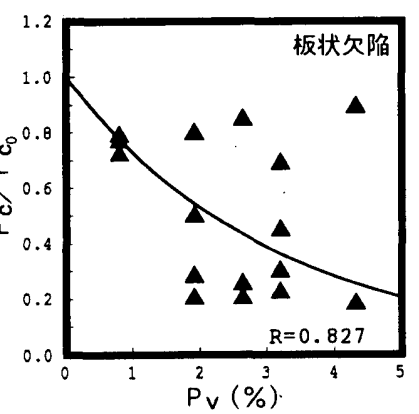

図17 Pvと $\mathrm{Fc} / \mathrm{Fc}_{0}$ との関係 および(6)式による推定曲線

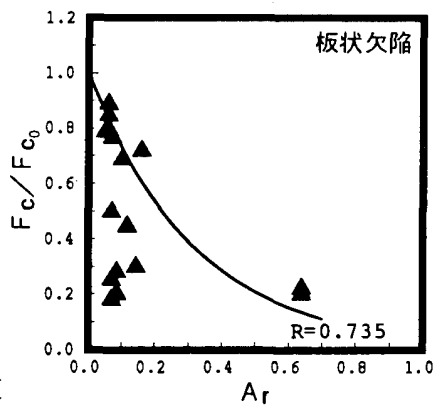

図 $18 \mathrm{Ar}$ と F / F coとの関係 およひ(7)式による推定曲線

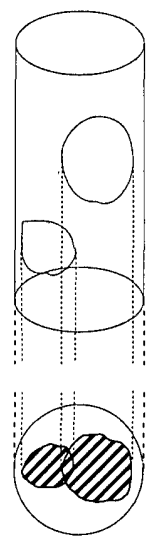

·図 19 A pの概要 


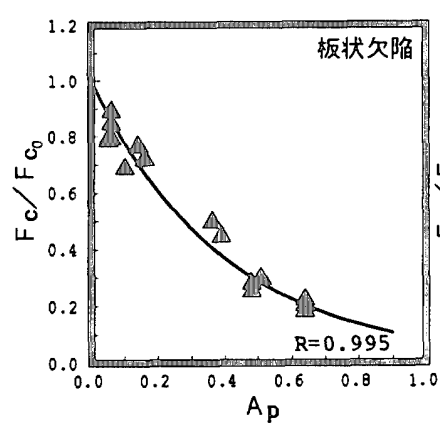

圈 $20 \mathrm{Apと} F \mathrm{c} / \mathrm{FC}_{0}$ との閔係 および(8)式による推定曲線

要を示す。Apを用いて回帰分析 を行い(8)式を得た。

$F c / F C_{0}=\exp (-2.490 A p)$
$(\mathrm{A} p \leqq 0.64)$
(8)式

図 20 に A と $\mathrm{Fc} / \mathrm{F}_{0}$ のの実測 值との関係、および(8)式による 推定曲線を示す。実測値と推定値 との対応は非常によく、板状欠陥 がコンクリートの強度に及ほす影 柏はPvやArよりApを用いたほ うが適切に表現できるといえる。 （3）欠陥性状の違いに影響を受け ない強度推定式の䛈运、提示 球状モデル欠陥を有する供試体 について、Apを説明変数として 回帰分析を行った結果 (9)式を得 た。

$$
F c / F c_{o}=\exp (-1.823 A p)
$$

$$
\text { ( } \mathrm{Ap} \leqq 0.64)
$$

図2 1 にApと F c/ F c 0 の実測値 との関係、および(9)式による推 定曲線を示す。

以上より、A pを説明変数とす

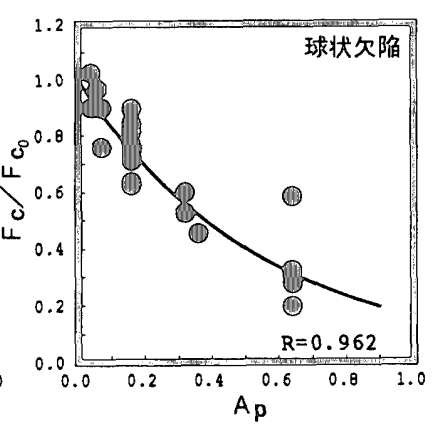

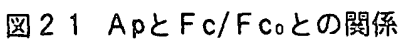
および(9)式による推定曲線

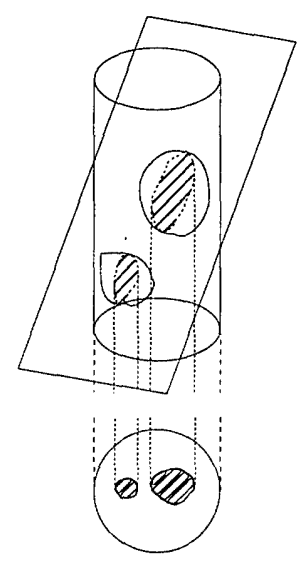

図22Azの概要

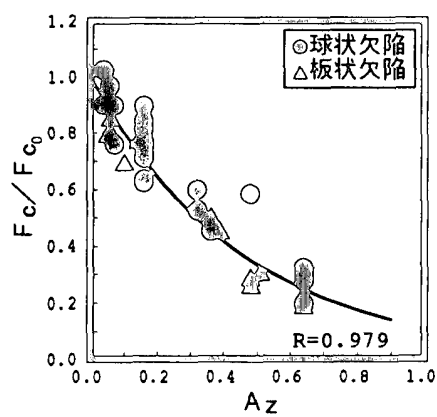

図 $23 \mathrm{Az}$ と F / F coとの関 係および(10)式による推定曲線 值との対応は、板状欠陷を有する ものではよい（図２０）。一方、 球状欠陥を有するものも悪くはないが（図２１）、Arを説明変数 とする強度推定式（図16）に比較すると、対応はやや劣り、十分 とはいえない。そこで、欠陥形状の違いに影響を受けない強度推定 式を提示するため、Ar、Apにかわるパラメータとして、供試体を 切断する平面によってできる久陥の断面を、戴荷方向に垂直な平面 に投影したものの面穦（投影欠陥断面䅡）の最大值と、供試体の载 荷方向に垂直な断面の面積との比（最大投影欠陥断面積比：Az) について検討した。図 22 に $\mathrm{A}$ の概要を示す。

$\mathrm{Az}$ を説明変数として回州分析を行った結果 $(10)$ 式を得た。

$$
F c / F c_{0}=\exp (-2.184 A z) \quad(\mathrm{Az} \leqq 0.64) \quad(10) \text { 式 }
$$

図 23 に $\mathrm{Az}$ と $\mathrm{Fc} / \mathrm{Fc}_{0}$ の実測值との関係および(10)式による推定
曲線を示す。実測值と推定値との対応は良好といえる。

以上より、本論文で対象としたマクロなモデル空隙欠陥の範囲で は、欠陷がモルタル・コンクリートの強度に及ほす影響はほほ $\mathrm{Az}$ によって表すことができるといえる。

\section{5. 結論}

1） マクロなモデル空隙欠陥を有するモルタル・コンクリートの 圧縮強度比は、空陌の量のみならず、形状、配置に大きく影響を受 ける。

2) 硬化セメントペースト中のミクロな空隙を主な対象とした既 往の強度推定式では、マクロな空隙欠陥を有するモルタル・コンク リートの压縮強度比を十分説明することはできない。

3）ママクロな空隙欠陥を有するコンクリートの圧縮強度比は、他 の条件が同じ場合、H/Cの小さい、すなわち高強度のコンクリート ほど低下する傾向にある。

4 ）球状および円板状のマクロな空隙欠陥がモルタル・コンクリ 一トの圧縮強度に及ぼす影啫は、空隙欠陥の量・寸法・配置に関わ らず、また、モルタル・コンクリートのH/C・骨材寸法・供試体寸 法に関わらず、最大投影欠骝断面檞比 $(\mathrm{Az})$ によってほぼ表すこ とができる。

\section{参羌文献}

1) コンクリートエ学協会耐久性研究会抄訳 : コンクリート構造物の耐久性, コンクリートエ学, vol.22, Na.1, pp.39-53, 1984.1

2 ）中埜 良昭： R C 構造物の損傷評価に関する最近の研究，コンクリート 工学, vol.29, №.5, pp.67-71, 1991.5

3 ）（社）日本コンクリートエ学協会編 : コンクリートの非破壞試戨法研究 委員会報告書，日本コンクリートエ学協会，1992

4) 渡辺 博志, 河野 広隆: コンクリート構造物の維持管理の合理化と健 全度診断技術，コンクリート工学，vol.33，№.9，pp.19-28，1995.9

5 ）（社）日本建築学会：建築工事標準仕様曾・同解説 5 鉄筋コンクリー 卜工事，日本建筑学会，pp.212-214，1997.1

6) E.Ryshkewitch: : Compression Strength of Porous Sintered Alumina and Ziluconia, Jour. of the Amer. Ceramic Society, vol.36, № 2, pp.6568,1953

7 ）羽原 俊祐 : コンクリートの構造とその物性，セメント・コンクリート， №.549, pp.31-43, 1992.11

8 ）菅谷 秀幸：骨材一セメントベースト界面，セメント・コンクリート， №.567, pp.46-48, 1994.5

9 ) 内川 浩 : セメントベーストと骨材の界面の構造・組織がコンクリート の品質に及ぼす影響, コンクリートエ学, vol.33, №.9, pp.5-17, 1995.

10）吉野 利幸, 鏮田 英治, 田畑 雅幸, 柳 敏幸: 空隙構造依存性に基 つくコンクリート強度推定法に関する研究, 日本建築学会論文報告集, 第312号，pp.9-17，1982.2

11）吉野利幸, 鑛田 英治, 桂 修: 空隙指標で表したコンクリート強度 式の提案とその検証，コンクリートエ学論文集，vol.7, No2, pp.65-77, 1996.7

（1997年 4 月10日原稿受理，1997年 9 月 26 日採用決定） 